\title{
Diversity, Prevalence and Risk Assessment of Nematode Parasites in Tatera indica found in Punjab State
}

\author{
Dimple Mandla, Neena Singla, Sukhmanpreet Kaur Brar, L.D. Singla1
}

10.18805/IJAR.B-4369

\begin{abstract}
Background: Present study was aimed to record diversity, prevalence and risk assessment of nematode parasites in Indian gerbil, Tatera indica, a wild rodent species found in crop fields.

Methods: Total 180 Indian gerbils ( $T$. indica) were live trapped from crop fields of Ludhiana, Punjab between April, 2019 to March, 2020 and examined for the diversity and prevalence of nematode parasites in liver and gastrointestinal tract.

Result: Only $33(18.33 \%)$ gerbils were found infected with four nematodes species i.e. Nippostrongylus brasiliensis (39.40\%), Calodium hepaticum (21.21\%), Trichuris muris $(21.21 \%)$ and Syphacia muris $(18.18 \%)$. Eggs of $N$. brasiliensis, T. muris and S. muris were found in faecal samples. Pale yellow lesions on surface of liver and subsequent histopathology of infected liver indicated the presence of $C$. hepaticum eggs entrapped in parenchyma. Host age $\left(\chi^{2}=8.78, P=0.03\right)$ and season $\left(\chi^{2}=9.21, P=0.01\right)$ significantly affected the prevalence of $N$. brassiliensis and $C$. hepaticum, respectively. Shannon-Weiner index and Species Evenness of nematode parasites were maximum in monsoon season (1.04 and 0.94 , respectively). Based on results proper rodent pest management is advised by integrated control measures at village level to prevent spread of diseases caused by them.
\end{abstract}

Key words: Endoparasites, Nematodes, Risk assessment, Tatera indica, Zoonosis.

\section{INRODUCTION}

Rodents are a big nuisance for mankind by being major household and agricultural pests (Singla and Babbar, 2010). Beside this, they are reservoirs of parasites of veterinary and public health importance resulting in socioeconomic and public health issues (Singla et al. 2008; Nateghpour et al. 2014; Singla et al. 2016). Disease transmission through rodents follows both direct and indirect routes (Singla et al. 2008; Ranjbar et al. 2017), by coming in contact with rodent excrements, through contaminated food, water and through arthropod vectors (Meerburg, 2009). Reports from Iran, Korea, Singapore and various other countries have indicated the presence of different nematode species in rodents (Pakdel et al. 2013; Kim et al. 2015; Mendenhall et al. 2017, respectively).

The Indian gerbil, Tatera indica is a wild rodent species belonging to family Muridae and subfamily Gerbillinae found in dry land crop fields, wastelands and near human establishments in arid and sub-humid habitats (Singla et al. 2017). It has also been found infested with many species of helminthes (Singla et al. 2008). Cosmopolitan nature and high reproductive rate of rodents is responsible for wide spread of diseases (Ogolla et al. 2019). Rodent borne zoonotic diseases are threat to public health and have emerged as epidemic from time to time for instance; capilliarisis caused by genus Calodium infected more than 1300 persons in 1967-68 and 1978-79 and 90 persons died in Philippine (Bair et al. 2004). Very few workers have set forth the regional studies on the occurrence of nematodes of $T$. indica. Considering this in view, the present study was conducted on nematodes of the Indian gerbil, $T$. Indica to know their diversity, prevalence and risk assessment.
Department of Zoology, Punjab Agricultural University, Ludhiana141004, Punjab, India.

1Department of Veterinary Parasitology, Guru Angad Dev Veterinary and Animal Sciences University, Ludhiana-141004, Punjab, India.

Corresponding Author: Neena Singla, Department of Zoology, Punjab Agricultural University, Ludhiana-141004, Punjab, India. Email: neenasingla1@gmail.com

How to cite this article: Mandla, D., Singla, N., Brar, S.K. and Singla, L.D. (2021). Diversity, Prevalence and Risk Assessment of Nematode Parasites in Tatera indica found in Punjab State. Indian Journal of Animal Research. DOI: 10.18805/IJAR.B-4369.

Submitted: 25-11-2020 Accepted:25-03-2021 Online: 29-04-2021

\section{MATERIALS AND METHODS}

\section{Collection and maintenance of animals}

The Indian gerbil, $T$. indica $(n=180)$ were collected from the crop fields of village Barewal Dogra, district Ludhiana of Punjab (India) using single catch live traps from April, 2019 to March, 2020 and brought to the rodent laboratory at Department of Zoology, Punjab Agricultural University, Ludhiana. The whole period was divided into three seasons i.e. summer (March-June), monsoon (July-October) and winter (November-February) with 60 gerbils collected in each season. Male and female gerbils were identified based on the presence of scrotum and vaginal opening, respectively, whereas young and mature gerbils were categorised on the basis of scrotal testes, perforated or imperforated vagina and body weight. Approval for use of animals was obtained from Institutional Animal Ethics Committee (Memo no. IAEC/ 2019/118-221 protocol no. GADVASU/2019/IAEC/51/17). 


\section{Collection and identification of parasites}

The gerbils were sacrificed using over dose of ketaminexylazine combination (>75 $+10 \mathrm{mg} / \mathrm{kg}$ body weight $\mathrm{i} / \mathrm{p})$, as per CPCSEA (Committee for the Purpose of Control and Supervision of Experiments on Animals) guidelines 2018 and dissected via mid ventral incision to record the presence of endoparasites in the visceral organs. The content of gastrointestinal tract was transferred into a petri dish containing normal saline solution and examined both with the naked eye and under a dissecting microscope. The nematode parasites collected were transferred to $70 \%$ ethanol for further identification (Taylor et al. 2016). The data obtained was used to determine the following parameters:

Percent host infected $=\frac{\text { Number of hosts infected }}{\text { Number of hosts examined }} \times 100$

Mean parasitic intensity $=\frac{\text { Number of parasites found }}{\text { Number of hosts infected }}$

Mean parasitic abundance $=\frac{\text { Number of parasites found }}{\text { Number of hosts examined }}$

\section{Faecal examination and histopathology}

Faecal floatation examination and micrometry of eggs was conducted to determine the presence and identification of eggs (Taylor et al., 2016). The length and width of different eggs were recorded as per the method described (Soulsby, 1982; Bowman, 1999). The histopathology of infected liver was performed as per Luna (1968).

\section{Statistical analyses}

The data was analysed using Pearson's Chi-square test at $5 \%$ level of significance by logistic analysis using SAS 9.4 software. The relative risk was determined as per the method described in Thrusfield (2005). Community characteristics such as species richness, species evenness and ShannonWeiner index for different nematode species were also determined (Mclntosh, 1967; Magurran, 2004; Ortiz-Burgos, 2016) as per the formulae given below:

Where,

$$
\text { Shannon-Wiener Index }(H)=\Sigma[(p i) \times \ln (p i)]
$$

$\mathrm{pi}=$ proportion of total sample represented by species $\mathrm{i}$ (obtained by dividing number of individuals of species i by total number of samples).

Species richness $(\mathrm{S})=$ number of species.

Species evenness $=\mathrm{H} / \mathrm{H}$ max .

Where, $H \max =\ln (S)$.

\section{RESULTS AND DISCUSSION} Overall parasitic prevalence

Out of the total $180 \mathrm{~T}$. indica consisting of 79 males, 101 females, 58 mature and 122 immature ones trapped from crop fields, 33 (18.33\%) were found infected with four species of nematode parasites viz. Syphacia muris, Trichuris muris, Nippostrongylus brasiliensis and Calodium hepticum.
Maximum numbers of gerbils (13, 39.40\%) were infected with $N$. brasiliensis followed by $T$. muris $(7,21.21 \%), C$. hepticum $(7,21.21 \%)$ and $S$. muris $(6,18.18 \%)$. Out of total 173 nematode parasites found in the intestine of $T$. indica, maximum number of parasites were of $S$. muris (134, $77.46 \%)$ followed by $N$. brasiliensis $(25,14.45 \%)$ and $T$. muris $(14,8.09 \%)$. Developmental stages of $C$. hepticum were found infecting the liver. In contrast to present study, Pakdel et al. (2013) found comparatively less infestation of C. hepaticum $(3.62 \%)$, T. muris $(14.49 \%)$ and $S$. muris $(2.89 \%)$ in wild rodent species. They did not report $N$. brassiliensis infection. Harandi et al. (2014), however, found $40 \%$ gerbils infected with nematodes in Iran. This variation can be due to the differences in climatic conditions of different study areas. In accordance with our findings, Kataranovski et al. (2011) observed infection of $N$. brassiliensis, $C$. hepaticum, T. muris and $S$. muris alongwith Heterakis spumosa in Norway rat, Rattus norvegicus. Recently, Mohtasebi et al. (2020) found wild rodent species, Dryomys nitedula infected with $T$. muris and a species of genus Syphacia alongwith other helminthes. Arzamani et al. (2017) identified T. trichuris and $N$. brassiliensis along with Syphacia oblevata in rodents inhabiting Iran.

\section{Morphometric analysis of eggs found in faecal samples}

Faecal examination revealed the presence of eggs of three nematode species i.e. S. muris, $N$. brasiliensis and T. muris. The eggs of $S$. muris were $72.50-82.25 \mu \mathrm{m}$ long and $22.00-$ 36.50 wide. These were asymmetrical, slightly flattened on one side and curved on the other side (Fig 1a). The eggs of T. muris were 67.50-70.75 $\mu \mathrm{m}$ in length and 35.00-40.50 $\mu$ min width having plugs at both the poles giving them acharacteristic bipolar shape (Fig 1b). The eggs of $N$. brasiliensis were comparatively small and ellipsoidal inshape. They had a thin shell and measured 50.00-70.00 $\mu \mathrm{min}$ length and 27.00-40.00 $\mu \mathrm{m}$ in width (Fig 1c). Eggs $C$. hepaticum were not found in faeces but histopathology of infected liver revealed the presence of eggs entrapped in liver parenchyma. These were 55.00-72.50 $\mu \mathrm{m}$ in length and 32.50-40.00 $\mu \mathrm{m}$ in width. The parenchyma showed granular degeneration, necrosis and microgranulomas (Fig 1d). In contrary to present study, Sharma et al. (2013) observed eggs of $C$. hepaticum in faecal samples along with eggs of S. muris, T. muris and other strongyle eggs.

\section{Morphology and morphometery of adult worms}

Length of the adult worm of $S$. muris inhabiting the ceacum of $T$. indica varied from 1.20-3.40 mm. They had characteristic oesophageal bulb at the anterior region (Fig 2a). T. muris was a small nematode of $10.00-20.00 \mathrm{~mm}$ length with cylindrical non-segmented body in caecum (Fig $2 \mathrm{~b}, \mathrm{c}) . \quad N$. brasiliensis (10.50-20.00 $\mathrm{mm}$ in length) was found to inhabit small intestine and ceacum. The males were having characteristic bursa at the posterior end (Fig 2d). $C$. hepaticum infection was found in the liver of $T$. indica in the form of pale yellowish lesions on the surface of liver (Fig 3). 


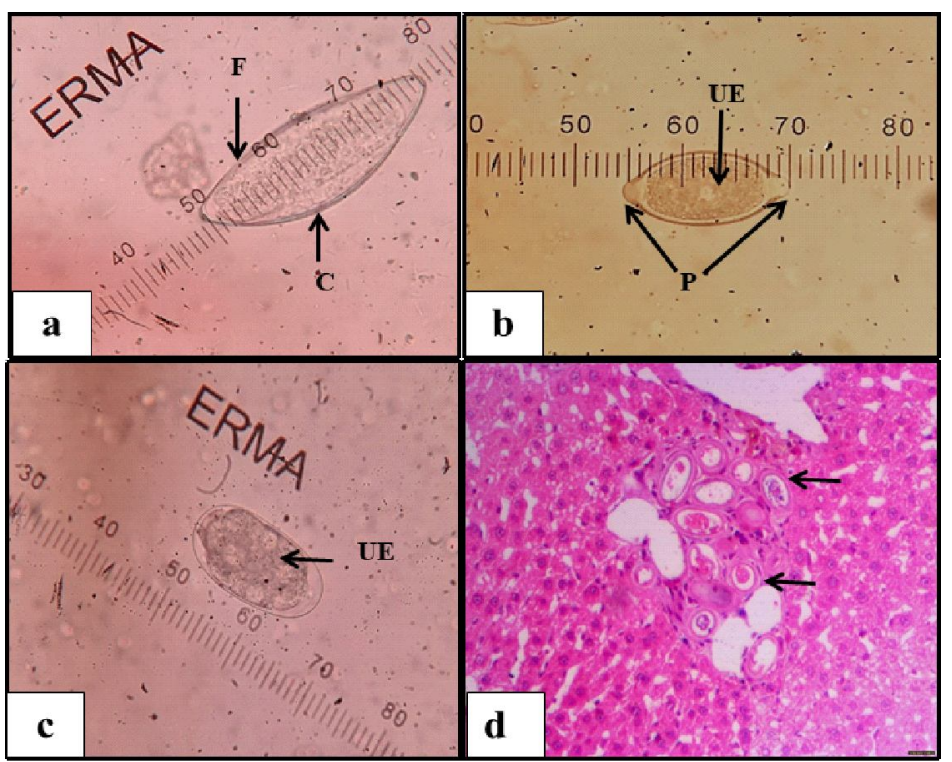

Fig 1: a) Egg of Syphacia muris at 400x with one side flattended ( $F)$ and other curved (C), b) Egg of Trichuris muris at 400x with polar plugs $(\mathrm{P})$ on two ends and undifferentiated embryo (UE) inside, c) Egg of Nippostrongylus brassiliensis at 400x with undifferentiated embryo (UE) inside and d) Eggs of Calodium hepaticum enclosed in liver parenchyma at 400x (arrows).

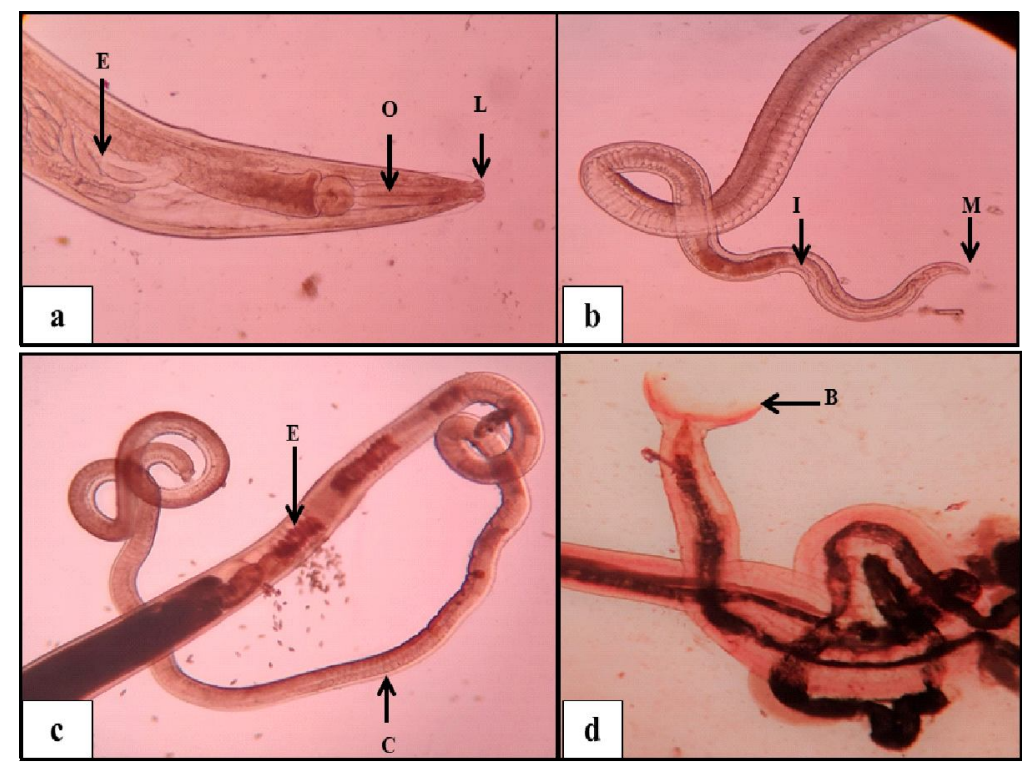

Fig 2: a) Anterior part of female Syphacia muris showing lips (L), oesophagus (O) and eggs (E), b) Anterior part of Trichuris muris showing mouth (M) and intestine (I), c) Posterior part of female Trichuris muris showing cuticular lining (C) and eggs (E) and d) posterior part of male Nippostrongylus brassiliensis showing bursa (B).

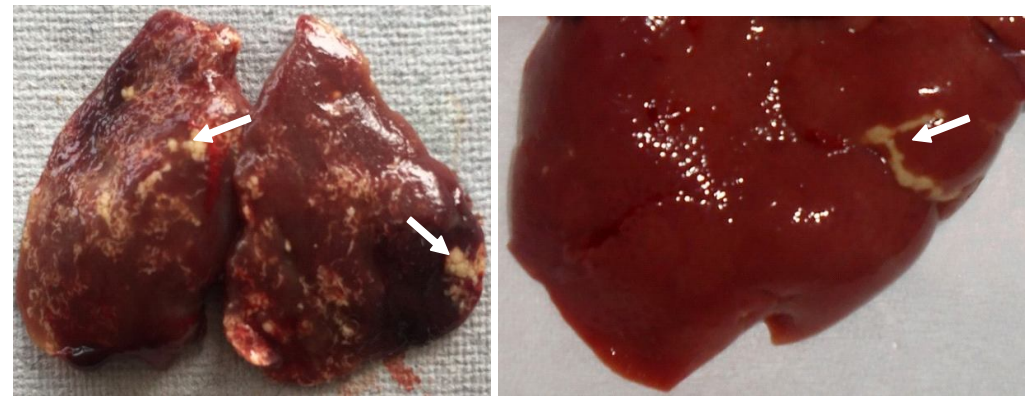

Fig 3: Liver of $T$. indica infected with $C$. hepaticum (arrows showing pale yellow lesions). 


\section{Community characteristics}

Shannon-Weiner index and Species Evenness of different nematode species found in $T$. indica were maximum in monsoon season ( 1.04 and 0.94 , respectively) followed by winter ( 0.80 and 0.72 , respectively) and summer seasons ( 0.45 and 0.40 , respectively). Also these indices were more in female ( 0.77 and 0.70 , respectively) and mature (1.01 and 0.91 , respectively) gerbils as compared to male $(0.70$ and 0.63 , respectively) and immature (0.43 and 0.39 , respectively) gerbils. In all, nematode parasites were more diverse and evenly distributed in monsoon season as compared to summer and winter seasons. Overall ShannonWeiner index (0.74) and Species Evenness (0.67) for nematode parasites were low in present study indicating less equitable distribution and abundance of species.

\section{Percent infection and risk assessment}

Total six (3.33\%) gerbils were found infected with $S$. muris. Higher infection rate was found in immature $(4.10 \%)$ and male $(5.06 \%)$ gerbils during summer season $(6.67 \%)$. However, statistically, season $\left(\chi^{2}=3.10, P=0.21\right.$ and $\left.\mathrm{df}=2\right)$, age $\left(\chi^{2}=0.68, P=0.40\right.$ and $\left.d f=1\right)$ and $\operatorname{sex}\left(\chi^{2}=1.3, P=0.25\right.$ and $\mathrm{df}=1$ ) had no significant effect on the infectivity of $S$. muris. Mean parasitic intensity and abundance were also more in summer season (24.75 and 1.65) in immature gerbils (23.60 and 0.96 ) indicating higher chances of infection of $S$. muris from immature gerbils during summer season. The mean parasitic intensity was more in female (27.50) gerbils, while the mean parasitic abundance was more in male (1.00) gerbils. The relative risk of occurrence of $S$. muris infection was more in summer season (3.99) through immature (2.38) and male gerbils (2.55) (Table 1 ).

Total seven (3.89\%) gerbils were found infected with $T$. muris. Higher rate of infection was observed in mature $(5.17 \%)$ and female $(4.95 \%)$ gerbils in summer season $(3.33 \%)$. Mean parasite intensity was higher in male gerbils (4.50), while it was similar across the seasons and age groups. Mean parasite abundance of $T$. muris was more during monsoon season in mature male gerbils (Table 1). Mature (1.58) and female (1.96) gerbils had relatively higher risk associated with them with respect to transmission of $T$. muris infection in summer season (3.33) (Table 1). But, statistically, the season $\left(\chi^{2}=0.29, P=0.86\right.$ and $\left.d f=2\right)$, host age $\left(\chi^{2}=0.37, P=0.53\right.$ and $\left.d f=1\right)$ and $\operatorname{sex}\left(\chi^{2}=0.69, P=\right.$ 0.40 and $d f=1$ ) had no significant effect on $T$. muris infection.

Table 1: Prevalence and risk assessment of different nematode parasites.

\begin{tabular}{|c|c|c|c|c|c|c|c|c|c|c|}
\hline \multirow{2}{*}{$\begin{array}{l}\text { Nematode species } \\
\text { Syphacia muris }\end{array}$} & \multicolumn{2}{|c|}{$\begin{array}{l}\text { Epidemiological } \\
\text { factors }\end{array}$} & \multirow{2}{*}{$\begin{array}{c}\begin{array}{c}\text { Animals } \\
\text { examined } \\
(n=180)\end{array} \\
60\end{array}$} & \multirow{2}{*}{$\begin{array}{c}\begin{array}{c}\text { Animals } \\
\text { infected } \\
(\%)\end{array} \\
4(6.67)\end{array}$} & \multirow{2}{*}{$\begin{array}{c}\begin{array}{c}\text { Number } \\
\text { of } \\
\text { parasites }\end{array} \\
99\end{array}$} & \multirow{2}{*}{$\begin{array}{c}\text { Mean } \\
\text { intensity } \\
24.75\end{array}$} & \multirow{2}{*}{$\begin{array}{c}\text { Mean } \\
\text { abundance }\end{array}$} & \multirow{2}{*}{$\begin{array}{c}\text { Chi } \\
\text { square } \\
\text { value } \\
3.10\end{array}$} & \multirow{2}{*}{$\begin{array}{l}\text { P value } \\
\text { (d.f.) } \\
0.21\end{array}$} & \multirow{2}{*}{$\begin{array}{c}\begin{array}{c}\text { Relative } \\
\text { risk }\end{array} \\
3.99\end{array}$} \\
\hline & Season & Summer & & & & & & & & \\
\hline & & Monsoon & 60 & $1(1.67)$ & 15 & 15.00 & 0.25 & & $(2)$ & 1.00 \\
\hline & & Winter & 60 & $1(1.67)$ & 20 & 20.00 & 0.33 & & & 1.00 \\
\hline & Age & Mature & 58 & 1 (1.72) & 16 & 16.00 & 0.27 & 0.68 & 0.40 & 1.00 \\
\hline & & Immature & 122 & $5(4.10)$ & 118 & 23.60 & 0.96 & & $(1)$ & 2.38 \\
\hline & Sex & Male & 79 & $4(5.06)$ & 79 & 19.75 & 1.00 & 1.30 & 0.25 & 2.55 \\
\hline & & Female & 101 & $2(1.98)$ & 55 & 27.50 & 0.54 & & $(1)$ & 1.00 \\
\hline \multirow[t]{7}{*}{ Trichuris muris } & Season & Summer & 60 & $2(3.33)$ & 4 & 2.00 & 0.06 & 0.29 & 0.86 & 3.33 \\
\hline & & Monsoon & 60 & $3(1.00)$ & 6 & 2.00 & 0.10 & & $(2)$ & 1.00 \\
\hline & & Winter & 60 & $2(1.67)$ & 4 & 2.00 & 0.06 & & & 1.67 \\
\hline & Age & Mature & 58 & $3(5.17)$ & 6 & 2.00 & 0.10 & 0.37 & 0.53 & 1.58 \\
\hline & & Immature & 122 & $4(3.28)$ & 8 & 2.00 & 0.07 & & $(1)$ & 1.00 \\
\hline & Sex & Male & 79 & $2(2.53)$ & 9 & 4.50 & 0.11 & 0.69 & 0.40 & 1.00 \\
\hline & & Female & 101 & 5 (4.95) & 5 & 1.00 & 0.05 & & $(1)$ & 1.96 \\
\hline \multirow{7}{*}{$\begin{array}{l}\text { Nippostrongylus } \\
\text { brassiliensis }\end{array}$} & Season & Summer & 60 & $5(8.33)$ & 10 & 2.00 & 0.16 & 0.66 & 0.71 & 1.67 \\
\hline & & Monsoon & 60 & $5(8.33)$ & 11 & 2.20 & 0.18 & & $(2)$ & 1.67 \\
\hline & & Winter & 60 & $3(5.00)$ & 4 & 1.33 & 0.06 & & & 1.00 \\
\hline & Age & Mature & 58 & $9(15.52)$ & 18 & 2.00 & 0.31 & 8.78 & 0.003 & 4.73 \\
\hline & & Immature & 122 & $4(3.28)$ & 7 & 1.75 & 0.06 & & $(1)$ & 1.00 \\
\hline & Sex & Male & 79 & $8(10.13)$ & 15 & 1.87 & 0.18 & 1.77 & 0.18 & 2.05 \\
\hline & & Female & 101 & $5(4.95)$ & 10 & 2.00 & 0.10 & & $(1)$ & 1.00 \\
\hline \multirow[t]{7}{*}{ Calodium hepaticum } & Season & Summer & 60 & $6(10.00)$ & - & - & - & 9.21 & 0.01 & 5.99 \\
\hline & & Monsoon & 60 & $1(1.67)$ & - & - & - & & $(2)$ & 1.00 \\
\hline & & Winter & 60 & $0(0.00)$ & - & - & - & & & - \\
\hline & Age & Mature & 58 & $1(1.67)$ & - & - & - & 1.07 & 0.30 & 1.00 \\
\hline & & Immature & 122 & $6(4.92)$ & - & - & - & & $(1)$ & 2.95 \\
\hline & Sex & Male & 79 & $2(2.53)$ & - & - & - & 0.69 & 0.40 & 1.00 \\
\hline & & Female & 101 & $5(4.95)$ & - & - & - & & $(1)$ & 1.96 \\
\hline
\end{tabular}


Total thirteen $(7.22 \%)$ gerbils were found infected with $N$. brassiliensis with higher rate of infection in mature (15.52\%) and male $(10.13 \%)$ gerbils in monsoon and summer seasons (8.33\% each). Statistically, the infestation of $N$. brassiliensis was not found to be affected by season $\left(\chi^{2}=0.66, P=0.71\right.$ and $d f=2)$ and $\operatorname{sex}\left(\chi^{2}=1.77, P=0.18\right.$ and $\left.d f=1\right)$ of the host. But age of the host significantly affected rate of $N$. brassiliensis infection $\left(\chi^{2}=8.78, P=0.003\right.$ and $\left.d f=1\right)$. Mean parasitic intensity and abundance were highest in monsoon season (2.20 and 0.18 , respectively). Mean parasitic infestation was higher in mature $(0.31)$ male $(0.18)$ gerbils.

Liver of seven $(3.89 \%)$ gerbils was found infected with C. hepaticum with higher infection in immature $(4.92 \%)$ and female gerbils $(4.95 \%)$ during summer season $(10.00 \%)$. Statistically, it was observed that season had direct impact on the infestation of this nematode $\left(\chi^{2}=9.21, P=0.01\right.$ and $\mathrm{df}=2$ ). No significant difference was, however, observed for host age $\left(\chi^{2}=1.07, P=0.30\right.$ and $\left.\mathrm{df}=1\right)$ and $\operatorname{sex}\left(\chi^{2}=\right.$ $0.69, \mathrm{P}=0.40$ and $\mathrm{df}=1$ ). Relatively higher risk of $C$. hepaticum infection was found associated with immature (2.50) and female (1.96) gerbils during summer season (5.99). Liver of infected animals was found containing numerous eggs of this parasite, however, the adult parasites could not be retrieved. No $C$. hepaticum infection was observed in winter season. In contrast to our study, Kataranovski et al. (2011) observed Capillaria sp. infection in rodents in winter season. Although rare, $C$. hepaticum is responsible for hepatic capillariosis in humans from different parts of the world (Fuehrer 2014).

Similar to present study, Moudgil et al. (2018) gave morpho-pathological description of fatal concurrent intestinal and renal parasitism in Columba livia domestica in India. In present study, a significant effect was observed of host age on $N$. brassiliensis infection (being higher in mature gerbils) and season (being higher in summer season) on $C$. hepaticum infection. This finding was seconded by the study of Hernandez et al. (2020) conducted in Southern Guatemala who observed higher infection of Nippostrongylus sp. in mature male rodents. However, Kataranovski et al. (2011) did not find effect of host age on any of the nematode infections. Rather they found significant affect of sex on the prevalence of $T$. muris and C. hepaticum. Coomansingh et al. (2009) reported that $N$. brasiliensis infection in adult rodents was much more than any other endoparasite infection which is in agreement with our present study. With $N$. brasiliensis infection, there is T-cell mediated immune response stimulation in the host resulting in expulsion of worms, however, this phenomenon fails to develop when infection occurs in rats having age less than 6 weeks and thus worms persist into adult life (Wakelin 1996). This could be the reason why $N$. brasiliensis infection was more in mature gerbils. Overall, in present study, higher nematode infection was observed in summer season as compared to winter and monsoon season as also observed by Kataranovski et al. (2011) which may be due to more foraging activity of rodents in summers thereby increasing their vulnerability to parasites (Eccard and Herde 2013; Tijjani et al. 2020). On the other hand, higher prevalence of nematode parasites was observed in sheep during winter and monsoon than in summer season by Pazhanivel et al. (2004). Pawar et al. (2020) have also reported higher nematode infestation $(70.58 \%)$ in captive wild animals. The presence of these nematode parasites in gerbils suggests the potential risk of rodent-borne disease transmission.

\section{CONCLUSION}

The present study indicated $T$. indica to be risk associated as being loaded with nematode parasites of veterinary and public health significance. Based on present study proper rodent pest management is advised using integrated control measures at village level in crop fields to avoid damage to crops and prevent spread of diseases caused by them.

\section{ACKNOWLEDGEMENT}

Present work was supported by the Indian Council of Agricultural Research, New Delhi, India in the form of All India Network Project on Vertebrate Pest Management at Punjab Agricultural University, Ludhiana, Punjab, India.

\section{REFERENCES}

Arzamani, K., Salehi, M., Mobedi, I., Adinezade, A., Hasanpour, H., Alavinia, M., Darvish, J., Shirzadi, M. and Mohammadi, Z. (2017). Intestinal helminths in different species of rodents in North Khorasan Province, Northeast of Iran. Iranian Journal of Parasitology. 12(2): 267-273.

Bair, M., Hwang, K., Wang, T., Liou, T., Lin, S., Kao, C., Wang, T. and Pang, K. (2004). Clinical features of human intestinal capillariasis in Taiwan. World Journal of Gastroenterology. 10(16): 2391-2393.

Bowman, D.D. (ed) (1999). Georgi's Parasitology for Veterinarians. WB Saunders, Philadelphia.

Coomansingh, C., Pinckney, R.D., Bhaiyat, M.I., Chikweto, A., Bitner, S., Baffa, A., Sharma, R. (2009). Prevalence of endoparasites in wild rats in Grenada. West Indian Veterinary Journal. 9(1): 17-21.

Eccard, J.A. and Herde, A. (2013). Seasonal variation in the behaviour of a short-lived rodent. BMC Ecololgy. 13: 43. doi: 10.1186/1472-6785-13-43.

Fuehrer, H.P. (2014). An overview of the host spectrum and distribution of Calodium hepaticum (syn. Capillaria hepatica): part1Muroidea. Parasitology Research. 113: 619-640. https:// doi.org/10.1007/s00436-013-3691-x.

Harandi, M., Madjdzadeh, S. and Ahmadinejad, M. (2014). Helminth parasites of small mammals in Kerman province, southeastern Iran. Journal of Parasitic Diseases. 40(1): 106-119.

Hernandez, W.C., Moran, D., Villatoro, F., Roderigurz, M. and Alvarez, D. (2020). Zoonotic gastrointestinal helminths in rodent communities in Southern Guatemala. The Journal of Parasitology. 106(3): 341-345.

Kataranovski, M., Mirkov, I., Belij, S., Popov, A., Petrovic, Z., Gacic, Z. and Kataranovski, D. (2011). Intestinal helminth infection of rats (Rattus norvegicus) in the Belgrade area (Serbia): the effect of sex, age and habitat. Parasite: journal de la SociétéFrançaise de Parasitologie. 18: 189-196. 
Kim, D.G., Park, J. H., Kim, J.L., Jung, B.K., Jeon, S.J., Lim, H., Lee, M.Y., et al. (2015). Intestinal nematodes from small mammals captured near the demilitarized zone, Gyeonggi province, Republic of Korea. The Korean Journal of Parasitology. 53(1): 135-139.

Luna, L.G. (1968). Manual of Histologic Staining Methods of the Armed Forces Institute of Pathology, $3^{\text {rd }}$ ed. McGraw-Hill Book Company, New York, 258.

Magurran, A. (2004). Measuring Biological Diversity. Oxford: Blackwell.

Moudgil, A.D., Singla, L.D., Gupta. K. (2018). Morpho-pathological description of first record of fatal concurrent intestinal and renal parasitism in Columba livia domestica in India. Indian Journal of Animal Research. 52(7): 1063-1067.

McIntosh, R.P. (1967). An index of diversity and the relation of certain concepts to diversity. Ecology. 48: 392-404.

Meerburg, B.G. (2009). Rodents are a risk factor for the spreading of pathogens on farms. Veterinary Microbiology. 142: 46465

Mendenhall, I.H., Ch'ng, L., Neves, E.S., Borthwick, S.A., Smith, G. (2017). High diversity of medically important gastrointestinal rodent-borne helminths in Singapore. Zoonoses and Public Health. Pages 1-6.

Mohtasebi, S., Teimouri A., Mobedi, I., Mohtasebi, A. (2020). Intestinal helminthic parasites of rodents in the central region of Iran: first report of a capillariid nematode from Dryomys nitedula. BMC Research Notes. 13: 461.

Nateghpour, M., Haghi, A.M., Akbarzadeh, K., Akhavan, A.A., Mohebali, M., Mobedi, I. and Farivar, L. (2014). Endoparasites of wild rodents in Southeastern Iran. Journal of ArthropodBorne Diseases. 9(1): 1-6.

Ogolla, F.O., Omondi, C. and Odhiambo, C. (2019). Assessment of wild rodents for endoparasites in Kirimiri Forest in Embu County, Kenya. International Journal of Advanced Research and Publications. 3(5): 14-22.

Ortiz-Burgos, S. (2016). Shannon-Weaver Diversity Index. In: Encyclopedia of Estuaries. [Kennish M.J. (ed)], Encyclopedia of Earth Sciences Series. Springer, Dordrech.

Pakdel, N., Naem, S., Rezaei, F., Chalehchaleh. (2013). A survey on helminthic infection in mice (Mus musculus) and rats (Rattus norvegicus and Rattus rattus) in Kermanshah, Iran. Veterinary Research Forum. 4(2): 105-109.

Pawar, P.D., Khasnis, M.W., Nighot, N.K., Deshmukh, A., Nimbalkar, V.G. and Singla, L.D. (2020). Parasitological surveillance and successful treatment of gastrointestinal parasites of captive wild animals with albendazole in a zoological collection. Indian Journal of Animal Research. 54(7): 895-899.
Pazhanivel, N., Napolean, R.E. and Raman, M. (2004). Prevalence of gastro-intestinal helminths in sheep of Dharmapuri district (Tamil Nadu). Indian Journal of Animal Research. 38(1): 53-55.

Ranjbar, M.J., Sarkari, B., Mowlavi, G.R., Seifollahi, Z., Moshfe, A., Khabisi, S.A. and Mobedi, I. (2017). Helminth infections of rodents and their zoonotic importance in Boyer-Ahmad District, Southwestern Iran. Iranian Journal of Parasitology. 12(4): $572-579$.

Sharma, P., Joshi, S., Vatsya, S. and Yadav, C.L. (2013). Prevalence of gastrointestinal helminth infections in rodents of Tarai region of Uttarakhand. Journal of Parasitic Diseases. 37(2): 181-184.

Singla, L.D., Singla, N., Parshad, V.R., Juyal, P.D. and Naresh, K.S. (2008). Rodents as reservoirs of parasites in India. Integrative Zoology. 3(1): 21-26.

Singla, N. and Babbar, B.K. (2010). Rodent damage and infestation in wheat and rice crop fields: District wise analysis in Punjab State. Indian Journal of Ecology. 37(2): 184-188.

Singla, N., Babbar, B.K., Singh, R., Kaur, N. and Tripathi, R.S. (2017). Bioecology of Indian gerbil Tatera indica (Hardwicke, 1807). All India Network Project on Vertebrate Pest Management, Department of Zoology, PAU, Ludhiana. Project Bulletin. pp. 20.

Singla, N., Dhar, P., Singla, L.D. and Gupta, K. (2016). Pathophysiological observations in natural concurrent infections of helminth parasites of zoonotic importance in the wild rodents, Bandicota bengalensis. Journal of Parasitic Diseases. 40(4): 1435-42.

Soulsby, E.J.L. (ed) (1982). Helminths, Arthropods and Protozoa of Domesticated Animals. Balliere Tindall, London.

Taylor, M.A., Coop, R.L. and Wall, R.L. (ed) (2016). Veterinary Parasitology. Wiley Blackwell, UK.

Thrusfield, M. (ed) (2005). Veterinary Epidemiology. Blackwell Science Ltd., UK. pp. 243.

Tijjani, M., Majid, R.A., Abdullahi, S.A. and Unyah, N.Z. (2020). Detection of rodent borne sparasitic pathogens of wild rats in Serdang, Selangor, Malaysia: A potential threat to human health. International Journal of Parasitology Parasites and Wildlife. 11: 174-82.

Wakelin, D. (1996). Immunity to parasites. $2^{\text {nd }}$ Ed. Cambridge University Press, Great Britain. 